\title{
Effect of fire on perennial grasses in central semiarid Argentina
}

\author{
DANIEL V. PELAEZ, ROBERTO M. BOO, MIRTA D. MAYOR, AND OMAR R. ELIA
}

Authors are professor and researcher, Departamento de Agronomía (UNS) and Comisión de Investigaciones Científicas (CIC); professor and researcher, Departamento de Agronomía (UNS) and Comisión de Investigaciones Científicas (CIC); professor, Departamento de Agronomía (UNS); research technician, Consejo Nacional de Investigaciones Científicas y Técnicas (CONICET). Departamento de Agronomía, Universidad Nacional del Sur, (8000) Bahía Blanca, Argentina.

\begin{abstract}
Fire is a key factor in the temperate semiarid region of central Argentina. The objectives of this work were to evaluate the effect of different fire intensities applied during different seasons under field conditions on the mortality of Piptochaetium napostaense (Speg.) Hack., Stipa tenuis Phil., and Stipa gynerioides Phil., 3 of the dominant grasses within the region and to determine their thermal death points in the laboratory. Ten plants of each species were exposed to low fire intensity $\left(300-400^{\circ} \mathrm{C}\right)$, high fire intensity $\left(500-600^{\circ} \mathrm{C}\right.$ ), and no fire (control) in April and December 1994, May 1995, and January 1996. Fire treatments were applied with a portable propane plant burner. The thermal death point was determined (during fall and spring) using the Wright's technique. Although mortality with high fire intensity was always higher than mortality with low fire intensity for all species, differences were not significant $(p>0.05)$. Pooling both treatments, the highest $(\mathrm{p}<0.05)$ average mortality for $P$. napostaense $(55 \%)$ and $S$. tenuis $(85 \%)$ was observed after the May burn. Average mortality for $S$. gynerioides was similar $(p>0.05)$ for all burning dates. Only after the May burn, was average mortality of $P$. napostaense and $S$. tenuis higher $(\mathrm{p}<0.05)$ than average mortality of $S$. gynerioides. The thermal death point was similar in all studied species. It was $65^{\circ} \mathrm{C}$ during the fall, and $68^{\circ} \mathrm{C}$ during the summer. This could explain, at least in part, similar mortalities (except after the May burn) between species and the date of burning found in this study.
\end{abstract}

Key Words: fire mortality, fire intensity, thermal death point, Piptochaetium napostaense (Speg.) Hack., Stipa tenuis Phil., Stipa gynerioides Phil.

Research was funded by Universidad Nacional del Sur (UNS), Comisión de Investigaciones Científicas (CIC), Consejo Nacional de Investigaciones Científicas y Técnicas (CONICET), and Agencia Nacional de Promoción Científica y Tecnológica.

Authors wish to thank Mr. Sergio Aman and Mr. Arturo Ferro for their field assistance during this research, and Mr. Raúl Cepeda who provided the land for this research.

Manuscript accepted 5 Nov. 00.

\section{Resumen}

El fuego es un factor clave en la región semiárida templada del centro de Argentina. Los objetivos de este trabajo fueron evaluar los efectos de diferentes intensidades de fuego aplicadas en distintas épocas del año bajo condiciones de campo sobre la mortalidad de Piptochaetium napostaense (Speg.) Hack., Stipa tenuis Phil., y Stipa gynerioides Phil., 3 de las gramíneas dominantes en la región y determinar sus puntos de muerte térmica en el laboratorio. Diez individuos de cada especie fueron expuestos a baja intensidad de fuego $\left(300-400^{\circ} \mathrm{C}\right)$, alta intensidad de fuego $\left(500-600^{\circ} \mathrm{C}\right)$, y ausencia de fuego (control) en abril y diciembre de 1994, mayo de 1995 y enero de 1996. Los tratamientos de fuego fueron aplicados con un quemador portátil. El punto de muerte térmica fue determinado en otoño y primavera usando la técnica de Wright. En todas las especies, la mortalidad con alta intensidad de fuego fue mayor a la mortalidad con baja intensidad de fuego, pero las diferencias no fueron significativas ( $p>$ $0.05)$. Combinando ambos tratamientos, el mayor $(p<0.05)$ promedio de mortalidad para $P$. napostaense $(55 \%)$ y $S$. tenuis $(85 \%)$ fue observado después de la quema de mayo. El promedio de mortalidad de $S$. gynerioides fue similar $(p>0.05)$ en todas las fechas de quema. Sólo luego de la quema de mayo, el promedio de mortalidad de $P$. napostaense y $S$. tenuis fue mayor $(p<0.05)$ que el promedio de mortalidad de $S$. gynerioides. El punto de muerte térmica fue similar en todas las especies estudiadas. El mismo fue de $65^{\circ} \mathrm{C}$ durante el otoño, y $68^{\circ} \mathrm{C}$ durante el verano. Esto podría explicar, al menos en parte, las mortalidades similares (excepto después de la quema de mayo) entre especies y fechas de quema encontradas en este estudio.

Death of perennial grasses following fire is usually attributed to heat. The likelihood of death of a whole plant will depend upon both the extent of injury to its component parts and which tissues are affected by the heat (Whelan 1995). Vascular plant tissues can be killed over a wide range of temperatures if the given temperature is maintained for the appropriate length of time (Wright and Bailey 1982). The lowest temperature that results in no survival after a fixed period of exposure, usually ten minutes, is referred as the thermal death point (Wright 1970). Combinations of temperature and exposure time have been used to measure death by heat in plants in relation to fire.

Characteristics such as temperature, intensity and duration, and season and frequency of fire have important effects on vegetation 
responses to fire (Gibson et al., 1990). Other factors such as phenological stage (Wright and Klemmedson 1965), amount of fuel per plant (Wright 1971), growth form (Wright 1986), localization of regrowth tissues (Whelan 1995), and climatic conditions after fire (Bunting 1985) can also modify the effect of fire on the mortality of perennial grasses.

Fire is a key factor in the Caldén District (Bóo 1990), a temperate, semiarid phytogeographic region of $40,000 \mathrm{~km}^{2}$ in central Argentina (Cabrera 1976), commonly known as the Caldenal. Some studies have investigated the effect of controlled fires on grass species in the Caldenal (Lutz and Graff 1980, Busso et al. 1993, Bóo et al. 1996, Peláez et al. 1997). However, information on the effect of different fire intensities during different seasons of the year on mortality of individual grass species is lacking, and thermal death points are unknown. The objectives of this work were to evaluate the effect of different fire intensities applied during different seasons of the year on the mortality of Piptochaetium napostaense (Speg.) Hack., Stipa tenuis Phil., and Stipa gynerioides Phil. under field conditions, and to determine their thermal death points in the laboratory. The first 2 species are abundant in the Caldenal and preferentially eaten by cattle, whereas $S$. gynerioides is largely neglected (Bóo et al. 1993, Bontti et al. 1999), thus increasing in abundance under heavy grazing (Distel and Bóo 1995).

\section{Study Area}

The study area is located in the southeastern corner of the province of $\mathrm{La}$ Pampa (38 $\left.45^{\prime} \mathrm{S}, 63^{\circ} 45^{\prime} \mathrm{W}\right)$, and comprises an area of 20 ha which has been closed to grazing since 1982 (Fig. 1). Vegetation, climate, and soil of the region have been described by others (INTA 1980, Bóo and Peláez 1991). The herbaceous layer is dominated by grasses such as Piptocahetium napostaense and Stipa tenuis. Stipa gynerioides and Stipa speciosa Trin. et. Rupr. are also abundant. The dominant woody species are Prosopis caldenia Burk., Prosopis flexuosa DC., Condalia microphylla Cav., and Larrea divaricata Cav.

Annual mean temperature is $15.3^{\circ} \mathrm{C}$ with June being the coldest month $\left(7^{\circ} \mathrm{C}\right)$ and January $\left(23.6^{\circ} \mathrm{C}\right)$ the warmest. Average annual precipitation is $344 \mathrm{~mm}$, and is concentrated in the fall and spring. The annual water deficit is about $400 \mathrm{~mm}$ (Peláez et al. 1994).

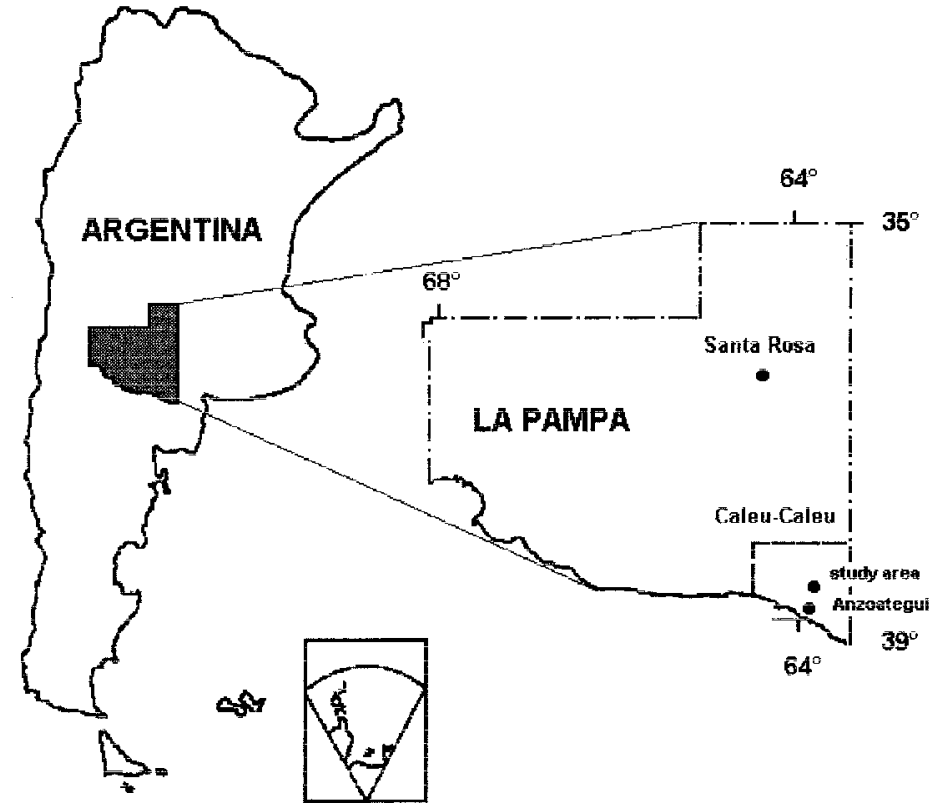

Fig. 1. Geographic localization of the study area. Department of Caleu-Caleu, province of La Pampa, Argentina.

The soil at the site is a Calciustoll, well drained with a medium to heavy texture. A petrocalcic horizon is found at an average depth of 40-60 cm (Peláez et al. 1997).

\section{Materials and Methods}

\section{Mortality in the Field.}

Individuals of Stipa tenuis, Piptochaetium napostaense, and Stipa gynerioides were randomly selected within the study area. Ten plants of each species were exposed to low fire intensity, high fire intensity, and no fire (control) in April and December 1994, May 1995, and January 1996.

Table 1. Mortality percentages of Piptochaetium napostaense, Stipa tenuis, and Stipa gynerioides treated with high fire intensity (HI), low fire intensity (LI), and no fire (CT). Treatment dates were April and December 1994, May 1995, and January 1996.

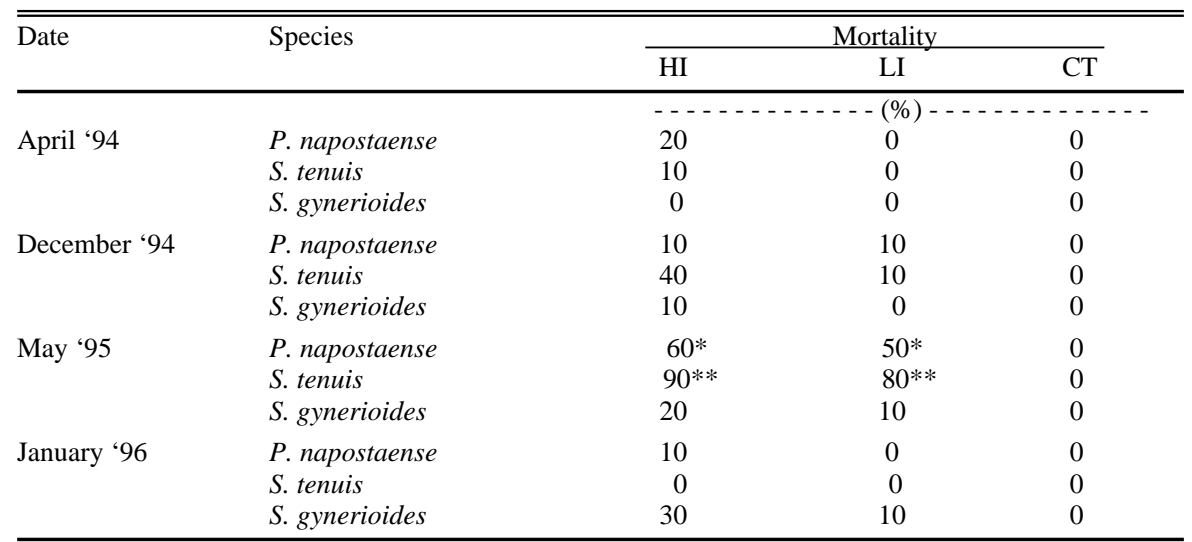

\footnotetext{
*,**significant at the 0.05 and 0.01 levels respectively.
}

Fire treatments were applied with a portable propane plant burner similar to the one described by Britton and Wright (1979). Low and high fire intensity treatments were obtained applying fire until the temperature in the crown had reached $300-400^{\circ} \mathrm{C}$ and $500-600^{\circ} \mathrm{C}$, respectively. Temperatures were measured at 1 second intervals with a type $\mathrm{K}$ thermocouple (chromel-alumel) located at the soil surface level in the center of the plant without touching the soil or the plant, in the same way as reported by Bóo et al. (1996). Temperatures were recorded by connecting the thermocouples to a Campbell 21 XL datalogger. Further details regarding 
Table 2. Basal diameter $(n=20)$ per plant for Piptochaetium napostaense, Stipa tenuis, and Stipa gynerioides in each burning date. In each row, values with the same letter are not significantly different $(p<0.05)$.

\begin{tabular}{lccc}
\hline \hline Date & \multicolumn{3}{c}{ Basal Diameter } \\
\cline { 2 - 4 } & P. napostaense & S. tenuis & S. gynerioides \\
\hline$-\ldots .4 \mathrm{a}$ & $7.2 \mathrm{a}$ & $11.4 \mathrm{~b}$ \\
April '94 & $6.6 \mathrm{a}$ & $6.9 \mathrm{a}$ & $12.4 \mathrm{~b}$ \\
December '94 & $6.1 \mathrm{a}$ & $6.6 \mathrm{a}$ & $10.7 \mathrm{~b}$ \\
May '95 & $6.7 \mathrm{a}$ & $7.0 \mathrm{a}$ & $8.7 \mathrm{~b}$ \\
\hline
\end{tabular}

Table 3. Average mortality percentages (high and low fire intensity treatments pooled) of Piptochaetium napostaense, Stipa tenuis, and Stipa gynerioides after the April and December 1994, May 1995, and January 1996 treatments. In each column, values with the same letter are not significantly different $(\mathbf{p}<0.05)$.

\begin{tabular}{lccc}
\hline \hline Date & \multicolumn{3}{c}{ Average Mortality } \\
\cline { 2 - 4 } & P.napostaense & S. tenuis & S. gynerioides \\
\hline$-10 \mathrm{~b}$ & $10 \mathrm{~b}$ & $5 \mathrm{~b}$ & $0 \mathrm{a}$ \\
April '94 & $55 \mathrm{a}$ & $25 \mathrm{~b}$ & $5 \mathrm{a}$ \\
December '94 & $5 \mathrm{~b}$ & $85 \mathrm{a}$ & $15 \mathrm{a}$ \\
May '95 & $0 \mathrm{~b}$ & $20 \mathrm{a}$ \\
January '96 & &
\end{tabular}

the burn techniques have been described by Peláez et al. (1997).

Surviving individuals of $S$. tenuis, $P$. napostaense, and $S$. gynerioides were counted at the end of the growing season following each fire. During each studied period and every 15-30 days, soil temperature $(n=10)$ and soil moisture $(n=10)$ at 10 and $30 \mathrm{~cm}$ of depth were determined using copper-constantan thermocouples and a gravimetric method (Wilcox 1951). Mortality data based on the number of individuals were analyzed using Chisquare (Snedecor and Cochran 1980).

\section{Thermal Death Point and Evaluation}

Duration of temperatures necessary to kill growing points of Stipa tenuis, Piptochaetium napostaense, and Stipa gynerioides were determined in 2 seasons of the year, summer and fall, following the technique described by Wright (1970). Summer and fall are the seasons with the highest occurrence of wildfires in the Caldenal. Fresh plants were randomly collected within the study site during April and December, 1997, and were kept in their sod prior to treatments. Culm bases $(\mathrm{n}=6) 2.5 \mathrm{~cm}$ long and stripped of dead leaves were randomly selected from these plants. They were placed in dry stoppled test tubes and heated for various lengths of time in a constant temperature bath at $5^{\circ} \mathrm{C}$ intervals from 50 to $100^{\circ} \mathrm{C}$. The culm bases were not placed in the test tubes until the air temperature within the test tubes was equal to the bath temperature. Temperatures within the test tubes were monitored with thermocouples connected to a Campbell $21 \mathrm{XL}$ datalogger.

After each heat treatment, the culm bases were incubated at $30^{\circ} \mathrm{C}$ in continuous darkness for 15 hours in a $0.5 \%$ solution of triphenyl tetrazolium chloride to test viability. Growing points were considered dead only if absolutely no red or pink coloring was visible.

\section{Results and Discussion}

A significant mortality $(\mathrm{p}<0.05)$ was only detected in Piptochaetium napostaense and Stipa tenuis $(\mathrm{p}<0.01)$ after the May, 1995 treatments (Table 1). Although no statistical differences $(p>0.05)$ were found, field observations showed that mortality with the high fire intensity was slightly higher than mortality with the low fire intensity. This trend was similar in all the studied species (Table 1). These results partially agree with those reported by Bóo et al. (1996) who found that mortality of $P$. napostaense, S. tenuis, and Stipa gynerioides increased significantly $(\mathrm{p}<0.01)$ with increasing fire intensity in most cases.

The high mortality, regardless of fire intensity, observed in P. napostaense and
S. tenuis (Table 1) after the May 1995 treatment date can be explained by the severe drought that occurred during that year (Fig. 2), or by the combined effects of fire and drought. Becker et al. (1997) found that regrowth of $P$. napostaense and $S$. tenuis after defoliation was drastically affected by water stress. Peláez et al. (1997) found that fire reduced viability of axillary buds of $P$. napostaense, $S$. tenuis, and $S$. gynerioides, which in turn may restrict the subsequent regrowth. Availability of soil water during plant regrowth after fire appears to be more significant than direct fire damage (Redmann 1978). According to Whelan (1995), the interaction between fire and other ecological factors, such as herbivory and drought, has the potential to produce mortality

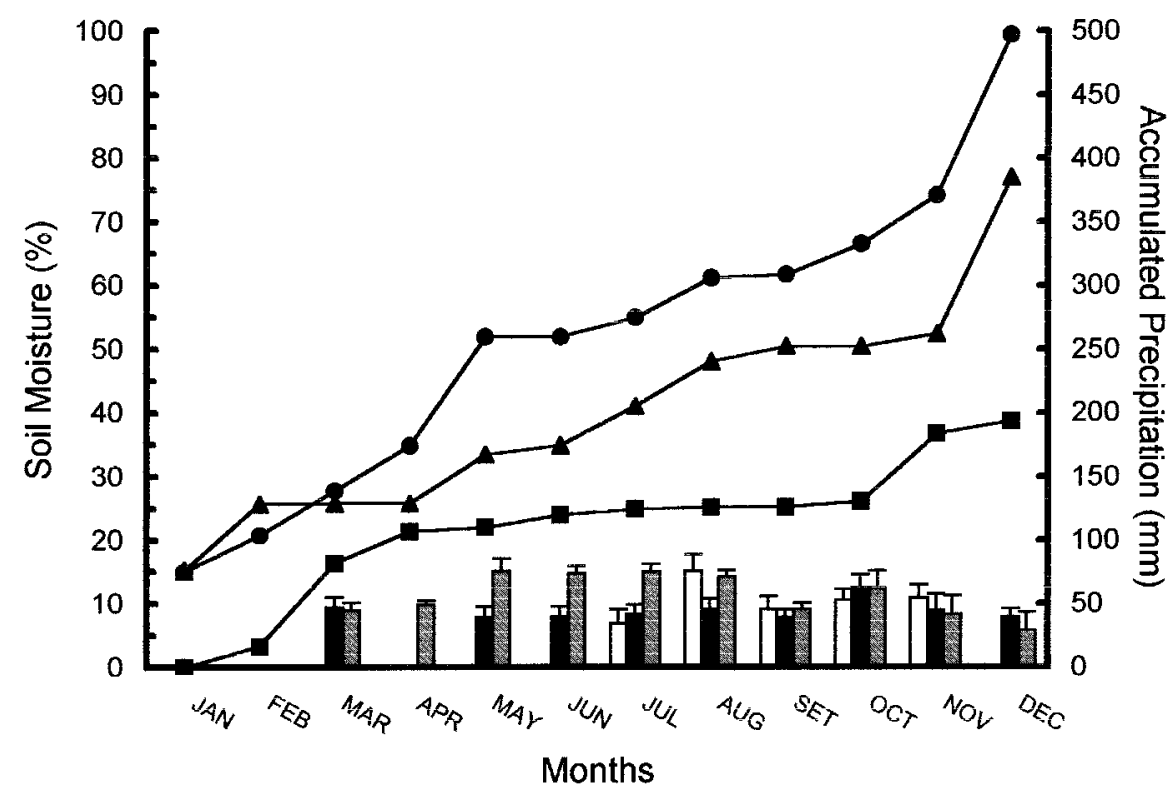

Fig. 2. Average soil moisture (\%) between $10-30 \mathrm{~cm}$ in depth during each study period: 1994 $\square, 1995 \square$, and $1996 \square$, and accumulated precipitation (mm): $1994 \Delta, 1995 \square$, and $1996 \bullet$. Each column is the mean of $\mathrm{N}=\mathbf{2 0}$, vertical bars represent mean standard deviations. 

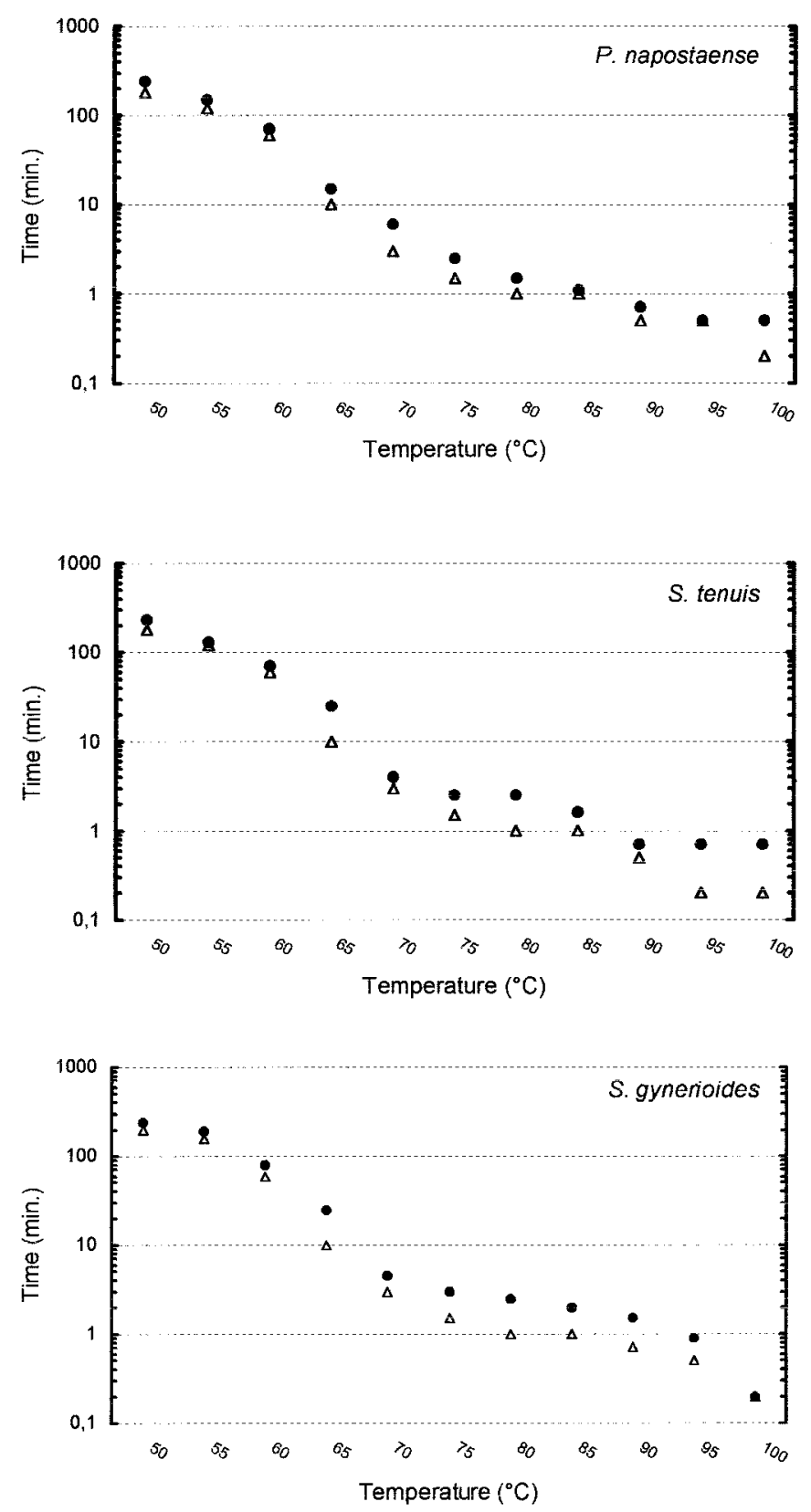

fall $\Delta \quad$ summer

Fig. 3. Time required to kill growing points of Piptochaetium napostaense, Stipa tenuis, and Stipa gynerioides at different temperatures during 2 seasons of the year.

where fire alone would have had little impact. The reason for the much lower mortality observed in S. Gynerioides after the May 1995 treatment (Table 1) is a matter of speculation. A higher number of growing points per plant in this species due to the fact that the burned plants of $S$. gynerioides had a greater size $(\mathrm{p}<0.05)$ than the burned plants of $S$. tenuis and $P$. napostaense (Table 2), could be a cause because some surviving plants of $S$. gynerioides had only a few active tillers after fire. On the other hand, the anatomical characteristics of the blades and stems of S. gynerioides (Metcalfe 1960, Lindström et al. 1998) would suggest that this species is very tolerant of water stress (Kramer 1983). On average, plants of S. gynerioides exposed to water stress grew more and had a higher number of new tillers than plants of $S$. tenuis (Busso personal communication). At least in part, the results obtained in our study would suggest that $S$. gynerioides is less susceptible to the combined effects of fire and drought than P. napostaense and S. tenuis.

The highest $(\mathrm{p}<0.05)$ average mortality (pooling both treatments) for $P$. napostaense and $S$. tenuis was observed after the May burn (Table 3). Average mortality for S. gynerioides reached a maximum of $20 \%$ after the January burn but differences among burn dates were not significant $(\mathrm{p}$ $>0.05$ ). When species' mortalities were compared within each burning date, only after the May burn was average mortality in P. napostaense (55\%) and S. tenuis $(85 \%)$ higher $(\mathrm{p}<0.05)$ than in S. gynerioides $(15 \%)$. This does not agree with results reported by Bóo et al. (1996) who found that mortality of $S$. gynerioides was higher than mortality of $P$. napostaense and $S$. tenuis after 1 accidental fire and 2 controlled fires. These differences might be due to different temperatures associated with different fuel loads reported by Bóo et al. (1996). They found heavier fuel accumulation and registered higher temperatures in the proximity of individuals of $S$. gynerioides than in the proximity of individuals of $P$. napostaense and $S$. tenuis. In our research temperatures were controlled, and the same for all species.

Several studies have emphasized the importance of season of fire on the mortality of perennial grasses. The importance of season has been related to moisture content (Wright 1971), phenological stage (Trollope 1984), and level of carbohydrate storage in plants (Wright and Klemmedson 1965). However, with the exception of the significant mortality found in P. napostaense and $\mathrm{S}$. tenuis after the May 1995 burn, we did not find a significant $(p>0.05)$ number of dead plants after the other treatment dates (Table 1). Plants that are resting in a dehydrated state or at the beginning of the growing cycle can be more fire-tolerant than those that are metabolically active and fully hydrated (Anderson et al. 1970). This would partly explain the results obtained in our study because fire treatments were applied at the beginning (April and May) and at the end (December and January) of the annual growing cycle (Distel and Peláez 1985).

An inverse relationship was found between time and temperature combinations which proved to be lethal to the growing points of $P$. napostaense, $S$. tenuis, and S. gynerioides (Fig. 3). In all species for a given temperature, more time was necessary to kill the growing points during the summer than during the fall. Jameson (1961), Wright (1970) and Whelan (1995) reported similar results. This seasonal variation in heat resistance 
was in general attributed to changes in the moisture content of the plants. However, Wright and Bailey (1982) suggested that other factors such as content of pectin, lignin, salt, sugar, and density of plant tissue might be involved in the tolerance of plant tissue to heat.

The thermal death points of $P$. napostaense, $S$. tenuis, and $S$. gynerioides were similar. It was $65^{\circ} \mathrm{C}$ during the fall, and $68^{\circ} \mathrm{C}$ during the summer (Fig. 3). The thermal death point at the cellular level for herbage of average mesophytic plants usually lies between 50 and $55^{\circ} \mathrm{C}$ (Whelan 1995). However, Jameson (1961) found that lethal temperatures of culms for four grasses varied between 60 and $74^{\circ} \mathrm{C}$. According to Wright and Bailey (1982), the widely quoted temperature of $60^{\circ} \mathrm{C}$ for one minute to kill plant tissue appears to be erroneous because the time to kill plants tissue at this temperature may vary from 2 to $60 \mathrm{~min}$, depending on moisture content of tissues. Thus, the death of plant tissue is an exponential function between temperature and time if the moisture content is constant. In general, the results obtained in different studies would indicate a similar capacity of vegetal tissues to tolerate heat exposure among different grass species. Therefore, survival of plant exposed to intensive fire must be related to the protection of critical tissues from excessive heat exposure, and/or their metabolic activity at the time of fire. The similar thermal death points of $P$. napostaense, S. tenuis, and S. gynerioides would further indicate similar mortalities (except after the May treatment) between species and date of burn found in this study.

The effect of fire on mortality of perennial grasses depends on several environmental and biotic factors. A species that suffers high mortality in one fire may survive well in another, not because of plant factors, but because the fires and/or postfire environmental conditions were different. Therefore, the final response of grasses to fire is the result of interactions among characteristics of the fire itself, processes that occur after fire such as climatic conditions and herbivory, and survival attributes of the plants in relation to the fire and to the post-fire processes.

\section{Literature Cited}

Anderson K.L., E.F. Smith, and C.E. Owensby. 1970. Burning bluestems range. J. Range Manage. 23:81-92.

Becker, G.F., C.A. Busso, and T. Montani. 1997. Effects of defoliating Stipa tenuis and Piptochaetium napostaense at different phe- nological stages: axillary bud viability and growth. J. Arid Environ. 35: 233-250.

Bontti, E.E., R.M. Bóo, L.I. Lindström, and O.R. Elia. 1999. Botanical composition of cattle and vizcacha diets in central Argentina. J. Range Manage. 52:370-377.

Bóo, R.M. 1990. Algunos aspectos a considerar en el empleo del fuego. (In Spanish). Rev. Fac. Agr. Univ. Nac. de La Pampa 5:63-80.

Bóo, R.M. and D.V. Peláez. 1991. Ordenamiento y clasificación de la vegetación en un área del sur del Distrito del Caldén. (In Spanish). Bol. Soc. Argent. Bot. 27:135-141

Bóo, R.M., L.I. Lindström, O.R. Elia, and MD. Mayor. 1993. Botanical composition and seasonal trends of cattle diets in central Argentina. J. Range Manage. 46:470-482.

Bóo, R.M., DV. Peláez, S.C. Bunting, O.R. Elia, and M.D. Mayor. 1996. Effect of fire on grasses in central semi-arid Argentina. J. Arid Environ. 32: 259-269.

Britton, C.M. and H.A. Wright. 1979. A portable burner for evaluating effects of fire on plants. J. Range Manage. 32:475-476.

Bunting, S.C. 1985. Fire in sagebrush-grass ecosystems: successional changes. p. 7-11. In: K. Sanders and J. Durham (eds), Rangeland fire effects: A symposium. Univ. Idaho Press, Moscow, Ida.

Busso, C.A., R.M. Bóo, and D.V. Peláez. 1993. Fire effects on bud viability and growth of Stipa tenuis in semiarid Argentina. Ann. Bot. 71:377-381.

Cabrera, A.L. 1976. Regiones fitogeográficas argentinas. In: Enciclopedia Argentina de Agricultura y Jardinería. Tomo II. Fasc. 1. (In Spanish). Acme SACI, Buenos Aires.

Distel, R.A. and D.V. Peláez. 1985. Fenología de algunas especies del Distrito del Caldén (Prosopis caldenia Burk.). (In Spanish). IDIA 441-444:35-40.

Distel, R. A. and R.M. Bóo. 1995. Vegetation states and transitions in temperate semiarid rangelands of Argentina, p. 117-118. In: N.E. West (ed.), Proc. Vth International Rangeland Congress, Salt Lake City, Utah.

Gibson, D.J., D.C. Hartnett, and G.L.S. Merrill. 1990. Fire temperature heterogeneity in contrasting fire prone habitats: Kansas tallgrass prairie and Florida sandhill. Bull. Torrey Bot. Club 117:349-356.

INTA, Provincia de La Pampa, and UN de La Pampa. 1980. Inventario Integrado de los Recursos Naturales de la Provincia de La Pampa. (In Spanish). INTA, Buenos Aires.

Jameson, D. A. 1961. Heat and desiccation resistance of tissue of important trees and grasses of the pinyon-juniper type. Bot. Gaz. 122:174-179.

Kramer, P.J. 1983. Water Relations of Plants. Academic Press, London.

Lindström, L.I., M.B. Mújica, and R.M. Bóo. 1998. A key to identify perennial grasses in central Argentina based on microhistological characteristics. Can. J. Bot. 76:1467-1475.

Lutz, E.E. and A.B. Graff. 1980. Efecto de la quema controlada sobre la pastura natural en un monte de la región semiárida pampeana. (In Spanish). Rev. Inv. Agr. 15:1-15.
Metcalfe, C.R. 1960. Anatomy of the Monocotyledons. Vol. I. Gramineae. Clarendon Press, Oxford.

Peláez, D.V., R.M. Bóo, O.R. Elia, and M.D. Mayor. 1997. Effect of fire intensity on bud viability of three grass species native to central semi-arid Argentina. J. Arid Environ. 37: 309-317.

Peláez, D.V., R.A Distel, R.M. Bóo, O.R. Elia, and M.D. Mayor. 1994. Water relations between shrubs and grasses in semi-arid Argentina. J. Arid Environ. 27:71-78.

Redmann, R.E. 1978. Plant and soil water potentials following fire in a northern mixed grassland. J. Range Manage. 31:443-445.

Snedecor, G.W. and W.G. Cochran. 1980. Statistical Methods, 7th Edition. Iowa State Univ. Press, Ames, Iowa.

Trollope, W.S.W. 1984. Fire in savanna. p. 151-217. In: P. de V. Booysen and N.M. Tainton (eds), Ecological Effects of Fire in South African Ecosystems. Springer-Verlag Press, New York, N.Y.

Whelan, R.J. 1995. The Ecology of Fire. Cambridge Univ. Press, Cambridge.

Wilcox, L.V. 1951. A method for calculating the saturation percentage from the weight of a known volume of saturated soil paste. Soil Sci. 72:233-237.

Wright, H.A. 1970. A method to determine heat-caused mortality in bunchgrasses. Ecol. 51:582-587.

Wright, H.A. 1971. Why squirreltail is more tolerant to burning than needle-and- thread. J. Range Manage. 24: 277-284.

Wright, H.A. 1986. Effect of fire on arid and semi-arid ecosystems-north american continent, p. 575-576. In: P.J. Joss, P.W. Lynch, O.B. Williams (eds.), Proceedings of the Second International Rangeland Congress, Canberra, Australia.

Wright, H.A. and A.W. Bailey. 1982. Fire Ecology. John and Sons Inc., New York.

Wright, H.A. and J.O. Klemmedson. 1965. Effect of fire on bunchgrasses of the sagebrush grass region in southern Idaho. Ecol. 46:680-688. 